\title{
KULTUROWY OBRAZ UKRAINY. BULGARZY JAKO MNIEJSZOŚĆ NARODOWA
}

Jerzy Hatłas, Butgarzy w pótnocnym Nadazowiu. Zapomniana diaspora, wyd. Biblioteka Uniwersytecka w Poznaniu, 2017, ss. 157.

\section{CULTURAL IMAGE OF UKRAINE. \\ BULGARIANS AS A NATIONAL MINORITY}

\begin{abstract}
The text is a review of Jerzy Hattas' book Bulgarians in the Northern Azov Sea region. The forgotten Diaspora. This review provides a brief overview of the seven chapters contained in the book. The book that is reviewed raises relevant and important issues of differentiation of the social world, migration, and sense of separateness and alienation proceeding from them, but also brings up questions of creating a community despite the differences experienced in the daily life. This book contributes to a better consideration of the phenomenon of national minorities in its various manifestations (linguistic, cultural, social, political) by people belonging to the world of science and social experts (politicians, public leaders, and activists). The book can be useful in a teaching process at different levels and in various specialties of education in different countries of Central Europe.
\end{abstract}

Key words: Bulgarian-language media; religious life of the Bulgarians; Northern Azov Sea region; Ukrainian-Russian border; Bulgarians; Bulgarian minority
HELENA KRASOWSKA Instytut Slawistyki Polskiej Akademii Nauk, Warszawa E-mail: bukowinianka@wp.pl

CITATION: Krasowska, H. (2018). Kulturowy obraz Ukrainy. Bułgarzy jako mniejszość narodowa. Sprawy Narodowościowe. Seria nowa, 2018(50) https://doi.org/10.11649/sn.1506

This work was supported by the author's own resources. No competing interests have been declared.

This is an Open Access article distributed under the terms of the Creative Commons Attribution 3.0 PL License (creativecommons.org/licenses/by/3.0/pl/), which permits redistribution, commercial and non-commercial, provided that the article is properly cited. (C) The Author(s) 2018.

Publisher: Institute of Slavic Studies, Polish Academy of Sciences 
Tekst jest recenzją książki Jerzego Hatłasa, Bułgarzy w pótnocnym Nadazowiu. Zapomniana diaspora. Recenzja ta zawiera krótkie omówienie siedmiu rozdziałów zawartych w książce. W recenzowanej książce podjęta jest stale aktualna i ważna problematyka zróżnicowania świata społecznego, migracji i idącego za tym poczucia odrębności, wyobcowania, ale też budowania wspólnoty pomimo dzielących i doświadczanych w toku codziennego życia różnic. Książka ta przyczynia się do lepszego rozpoznania fenomenu mniejszości narodowej w różnych jej aspektach (językowym, kulturowym, społecznym, politycznym) przez osoby należące do świata nauki oraz przez praktyków społecznych (polityków, działaczy i aktywistów). Poszczególne partie książki mogą być pomocne w procesie dydaktycznym na różnych szczeblach i kierunkach kształcenia w różnych krajach Europy Środkowej.

Słowa kluczowe: bułgarskojęzyczne media; życie religijne Bułgarów; Nadazowie; pogranicze ukraińsko-rosyjskie; Bułgarzy; mniejszość bułgarska

K siążka pod tytułem Bułgarzy w północnym Nadazowiu. Zapomniana diaspora Jerzego Hatłasa (2017) zawiera siedem rozdziałów, wstęp i zakończenie. Pierwszy rozdział traktuje o przesiedleniach Bułgarów na tereny wokół Morza Azowskiego. Autor szczegółowo omawia opisywany teren oraz jego mieszkańców, zatem omawia mniejszość bułgarską zamieszkującą Ukrainę i Mołdawię - wprowadza czytelnika w problematykę badawczą. Dalsze części pierwszego rozdziału omawiają osiedlenia Bułgarów na opisywanym terenie. Jerzy Hatłas zaznacza, że „W efekcie fali przesiedleńczej w końcu 1863 roku w nowych wsiach zamieszkało 5500 rodzin bułgarskich (13 660 mężczyzn i 12500 kobiet) ... Masowe przesiedlenie ludności bułgarskiej do Nadazowia miało miejsce w przedziale chronologicznym od wiosny 1861 do końca 1863 roku" (Hatłas, 2017, s. 36). Rozdział ten jest dobrze przemyślany i wnosi nową wiedzę dla polskiego czytelnika.

W kolejnym rozdziale, „Bułgarzy nad Morzem Azowskim w carskiej Rosji”, autor szczegółowo omawia osiedlenie się Bułgarów, podsumowując go następująco: "Do roku 1914 liczba Bułgarów w Nadazowiu wzrosła do 45 000. W czasach carskich i związanym z nimi podziałem administracyjnym kraju przygniatająca liczba Bułgarów mieszkała na obszarze powiatu (ujezdu) berdiańskiego" (Hatłas, 2017, s. 61). Ze wszech miar godny uwagi podrozdział o życiu religijnym Bułgarów, w którym dowiadujemy się szczegółowo na temat istniejących tam kościołów. Bardzo ważne jest to, że na zakończenie tego rozdziału autor wyjaśnia czytelnikowi różnicę nazewniczą pomiędzy cerkwią a domem modlitwy.

Trzeci rozdział opisuje życie Bułgarów po 1917 roku na prezentowanym terenie. W okresie między dwoma wojnami światowymi Ukraina była całkowicie uzależniona od Rosji. Wszystkie decyzje gospodarcze, także dotyczące polityki rolnej, podejmowano w Moskwie. Ukrainę dotknął proces tzw. rozkułaczania, który polegał na likwidacji gospodarstw zamożniejszych rolników, a następnie odbieraniu wszystkim płodów rolnych jako obowiązkowych dostaw. Wywołało to początek klęski głodu w latach 1921-1922.

O tragicznej sytuacji podczas głodu w bułgarskich wsiach Nadazowia może świadczyć chociażby telegram z dnia 22 listopada 1921 r. z opisem traumatycznej sytuacji we wsi Romanowka (obecnie Bułgarka), która jeszcze niedawno uchodziła za bogatą i dobrze zarządzaną. Ludzie setkami leżeli w domach opuchnięci z głodu. Rodzice nie mogąc wykarmić swoich dzieci przynosili je do urzędu gminy i tam pozostawiali (Hattas, 2017, s. 74).

Osobny podrozdział poświęcony jest Wielkiemu Głodowi. Kolejna klęska głodu, wywołana sztucznie przez władze radzieckie, nadeszła w latach 1932-1933. Określa się ją nazwą Wielki Głód. W niektórych rejonach na wschodzie i południu Ukrainy śmierć z po- 
wodu głodu poniosło 20-25\% mieszkańców. Wielu naukowców twierdzi, że Wielki Głód był ze strony władz radzieckich świadomym aktem ludobójstwa. Andrew Wilson pisze: „Wielki Głód był zaplanowanym i niezwykle brutalnym manewrem strategicznym, ale manewrem w wojnie nie tyle narodowej, ile ideologicznej" (Wilson, 2004, s. 149). Kolektywizacja rolnictwa dotknęła wszystkie grupy narodowościowe, ale wywłaszczenia wśród Bułgarów, Greków i Niemców były intensywniejsze. W podrozdziale "Szkolnictwo i kultura” znajdujemy następujący fragment:

Bułgarscy uchodźcy polityczni na radzieckiej Ukrainie mieli duże zasługi (w drugiej połowie lat 20.) w powstaniu prasy w języku bułgarskim. Już w roku 1924 zaczęto wydawać pierwsze czasopismo w języku bułgarskim "Sierp i Młot". Mimo jego silnie ideologicznego charakteru cieszyło się dużym powodzeniem. W roku 1926 zmieniło ono swoją nazwę na "Radziecka Wieś" a po roku 1930 na "Kolektywista”. Nakład wynosił aż ponad 25000 egzemplarzy. W tym czasie w różnych miejscach Nadazowia wydawano jeszcze 7 innych czasopism (Hattas, 2017, s. 80).

Kolejny podrozdział dotyczy represji, szczegółowo opisano w nim zwłaszcza niszczenie religii i budynków modlitewnych.

Czwarty rozdział dotyczy okupacji hitlerowskiej oraz przesiedleń. Autor szczegółowo analizuje migracje, a z braku literatury przedmiotu podaje następujące zdanie:

Dokładna liczba Bułgarów przesiedlonych z Nadazowia do Bułgarii w latach 1943-1944 nie jest znana. Brakuje odpowiedniej dokumentacji a ta, która istnieje nie zawsze jest ścisła (Hatłas, 2017, s. 95).

Mniejszość bułgarską podobnie jak Polaków i Niemców dotknęła również przymusowa deportacja.

Władze radzieckie ze Stalinem na czele nie uznały woli nadazowskich Bułgarów powrotu do swej starej ojczyzny. Traktowano ich nadal jako obywateli radzieckich (czyli swoją własność, pomimo, że prawie wszyscy przesiedleńcy przyjęli już obywatelstwo bułgarskie), na dodatek jako zbiegów i zdrajców, których należało ukarać. Czekano tylko na okazję, aby ich wszystkich zabrać z Bułgarii z powrotem w granice ZSRR (Hatłas, 2017, s. 97).

W książce znajdziemy także opis tych Bułgarów, którzy zostali w Bułgarii, uchronili się oni przed deportacją.

W latach 1946-1947 Ukrainę dotknęła kolejna klęska głodu. Przyczyny leżały częściowo w warunkach klimatycznych (susza), jednak głównym powodem było nałożenie przez Moskwę na republikę zawyżonego i brutalnie egzekwowanego planu dostaw produktów rolnych. Liczbę ofiar głodu ocenia się na 300-500 tysięcy osób. Notowane były wówczas często przypadki kanibalizmu. Po śmierci Stalina w 1953 roku Ukrainą nadal kierowała partia komunistyczna. Procesy rusyfikacyjne nasilały się wraz z lansowaniem propagandowej tezy o powstaniu w ZSRR narodu "radzieckiego", a w konsekwencji - uznaniu języka rosyjskiego za jeden z czynników integrujących społeczeństwo.

Siódmy rozdział, „W niepodległej Ukrainie”, podaje liczbę osób narodowości bułgarskiej oraz dane o używaniu i uczeniu się języka bułgarskiego, o szkolnictwie, zatem też o organizacjach i stowarzyszeniach bułgarskich. Ciekawe opisy dotyczą kultury, massmediów, kuchni i tradycji. Jerzy Hatłas podkreśla, że

na zanikanie języka i kultury bułgarskiej w Nadazowiu złożyło się kilka czynników. Wymienić tutaj można takie jak: asymilacyjna i rusyfikacyjna polityka państwa radzieckiego, głody, w wyniku których we wsiach bułgarskich masowo osadzano ludność innych narodowości, małżeństwa mieszane, ucieczka ludzi młodych do miast, brak edukacji w języku ojczystym, a nawet 
nauki języka bułgarskiego, brak możliwości rozwoju własnej kultury i pielęgnowania tożsamo-

ści narodowej (Hatłas, 2017, s. 130).

W zakończeniu autor podsumowuje następująco: „Diaspora bułgarska w Nadazowiu jest drugim co do wielkości skupiskiem ludności bułgarskiej (poza granicami Republiki Bułgarii) po Besarabii" (Hatłas, 2017, s. 145).

Autor znakomicie dobrał i wykorzystał literature przedmiotu widniejącą jako Wybrana literatura. Baza źródłowa jest wykorzystana prawidłowo. Podjęty przez autora wysitek badawczy zaowocował bardzo dobrym opracowaniem, które wpisuje się w nurt badań nad kulturą bułgarską, dopełnia prace innych badaczy. Warto wspomnieć, że każda monografia dotycząca mniejszości bułgarskiej na Ukrainie jest warta uwagi, ze względu na sam problem badawczy oraz różnorodność dziedzin badawczych.

Książka podejmuje stale aktualną problematykę zróżnicowania świata społecznego, migracji i idącego za tym poczucia odrębności, wyobcowania, ale też budowania wspólnoty pomimo dzielących i doświadczanych w toku codziennego życia różnic. Przyczynia się do lepszego rozpoznania fenomenu mniejszości narodowej w różnych jej aspektach (językowym, kulturowym, społecznym, politycznym) przez osoby należące do świata nauki oraz przez praktyków społecznych (polityków, działaczy i aktywistów). Poszczególne partie książki mogą być pomocne w procesie dydaktycznym na różnych szczeblach i kierunkach kształcenia w różnych krajach Europy Środkowej.

\section{BIBLIOGRAFIA}

Hatłas, J. (2017). Bułgarzy w północnym Nadazowiu: Zapomniana diaspora. Poznań: Biblioteka Uniwersytecka w Poznaniu.

Karnaukh, A. (2015). Pomiędzy ukraińskością a sowieckością: Ukraińcy, Rosjanie i Bułgarzy na Zaporożu. Kraków: Nomos.

Krasowska, H. (2010). Struktura narodowościowa regionów południowo-wschodniej Ukrainy. Sprawy Narodowościowe, 2010(36), 189-202.

Krasowska, H. (2012). Mniejszość polska na południowo-wschodniej Ukrainie. Warszawa: Slawistyczny Ośrodek Wydawniczy.

Krasowska, H. (2016). Bułgarzy w obwodzie zaporoskim na Ukrainie: Tożsamość kulturowo-narodowa. Balcanica Posnaniensia: Acta et studia, 23, 109-119.

Suchomłynow, L. (2008). Specyfika polskości na Ukrainie Wschodniej: Tworzenie czy odrodzenie? W Kształtowanie pamięci narodowej: Polska i Ukraina: Referaty konferencji międzynarodowej, Charków, 12 maja, 2007 r. Kharkiv: "Maiĩdan”.

Wilson, A. (2004). Ukraińcy (M. Urbański, Tłum.). Warszawa: Świat Książki. 